\title{
Development Assistance from the South: Comparative Analysis of Chinese and Indian to Ethiopia
}

\author{
Gedion G. Jalata* \\ Macroeconomic Policy Division, The United Nations Economic Commission for Africa (UNECA), \\ Addis Ababa, Ethiopia \\ Email: gediongam@yahoo.com
}

Received December 23 ${ }^{\text {rd }}, 2013$; revised January 25 ${ }^{\text {th }}, 2014$; accepted February $7^{\text {th }}, 2014$

\begin{abstract}
Copyright (C 2014 Gedion G. Jalata. This is an open access article distributed under the Creative Commons Attribution License, which permits unrestricted use, distribution, and reproduction in any medium, provided the original work is properly cited. In accordance of the Creative Commons Attribution License all Copyrights (C) 2014 are reserved for SCIRP and the owner of the intellectual property Gedion G. Jalata. All Copyright @ 2014 are guarded by law and by SCIRP as a guardian.
\end{abstract}

\begin{abstract}
China and India, as re-emerging donors, are not new to Ethiopia and Africa. Both countries have been providing aid to Ethiopia since Emperor Haille Sillasie's time and to Africa since the end of colonial period, at least as long as the West. However, until recently the aid flow from both countries was very minimal, which is unlike the aid from western countries. Development assistances from these two countries also have similarities in some important and inter-related respects. Both countries give monetary and non-monetary forms of assistance; both countries are also motivated by a combination of strategic, political interests and mutual benefits with commercial intent. In this regard, they are similar to traditional western donors in that their aid practices are tied with some conditionalities-equipment, companies and labour as well as services. Yet neither country has conditions on governance, democracy and human rights. Meanwhile, both China and India have valuable contributions to make towards Ethiopia's development in the spirit of South-South cooperation, which needs to be understood in the context of the changing global development assistance architecture. The present study indicates that the development assistances from China and India to Ethiopia do have both opportunities and risks. The researcher also recommends policy interventions to minimize the risks and maximize the benefits of the development cooperation, which can be implemented unilaterally by Ethiopia and also by China and India as well as through the cooperation of the three.
\end{abstract}

Keywords: Development Assistance; Aid; China; India; Ethiopia

\section{Introduction}

A comparative study of Chinese and Indian aid to Ethiopia is relevant and has profound consequence to Africans and others concerned with Africa. The method of data collection relies on both primary and secondary sources. With regard to the analysis of the research, it adopts analytical, descriptive, and critical approaches. The article is organized in such a way that the first part addresses scope, growth and nature of Chinese and Indian development assistance to Ethiopia. The second part looks at the comparative analysis of Chinese and Indian aid to Ethiopia. The third section deals with opportunities and risks involved in Chinese and Indian aid to Ethiopia and finally the article ends with conclusion and policy recommendations.

\section{Scope, Growth and Nature of Chinese and Indian Development Assistance to Ethiopia}

As many western governments decrease their development aid, many African states are turning to China and India to finance their development projects, while offering market, mineral, diplomatic support and other natural resources in exchange. China's and India's economic assistances to African

\footnotetext{
*This article was written in his personal capacity.
}

countries have shifted from holding a strong ideological alignment of the cold war period to being led by market and resource and political consideration by providing huge aid packages in the form of grants and soft loans. The Beijing consensus promoted value free; no strings attached approach to aid than the Washington consensus.

China's and India's definitions, principles and mechanisms pertaining to aid differ slightly from those of the more established donor community in the OECD, which is partly attributed to its distinct economy and socio-political fabric. The development assistance of China and India has its own specific development cooperation dimension that combines monetary and non-monetary forms of aid. It also typically combines aid with investment and trade and enhanced market access opportunities known as the "Asian Mode of Development Assistance". This type of development assistance attaches no political strings, but it ties aid to labor and/or material inputs from the donor, relies on projects rather than programme aid, and target different sectors of the economy known as development investment than development assistance of the west. Such type of development cooperation comes based on requests from the recipient country and has a long time horizon with profit orientation.

Aid in this sense is geared to promote trade and investment, 
and serves as market entry for companies by providing the necessary infrastructure to reduce operational cost. This approach of aid was used by Japan in the 1970s and 80s. The Japanese offered a line of credit to secure needed raw materials, imports, promote its exports, strengthen its business sector, and ensure friendly relations with countries whose products and markets were potentially important to the Japanese economy. China and India are also using similar types of deals in their development cooperation assistance to Africa.

\section{A Review of China's Development Assistance to Ethiopia}

China's ties with Ethiopia are historic since both are the oldest nations in the world. Yet the Sino-Ethiopian economic cooperation including aid officially began in the early 1970's and remained low until 1995. The Sino-Ethiopian economic cooperation was restored in 1991 when Ethiopian People Revolutionary Democratic Front (EPRDF), the incumbent ruling party, came to power in Ethiopia. Especially after 1995, the bilateral economic cooperation witnessed marked progress and rapid development in different areas. During the late Prime Minister Meles Zenawi's visit to China in 1995, the two countries signed economic and technical cooperation agreements. Meles also reached a good understanding with prominent Chinese enterprises and corporations. On the other hand, when the Chinese President, Jiang Zemin, made an official visit to Ethiopia in 1997, the two countries signed agreements on trade, investment and joint commercial ventures, and science and technology (Gedion \& Venkataraman, 2009).

A Joint Ethiopia-China Commission (JECC) was established in 1998 by the Ethiopian Ministry of Finance and Economic Development (MOFED) and Chinese MOFCOM to focus on trade and economic cooperation. JECC has been serving as an economic forum for dialogue where agreements are negotiated, reviewed, and areas of mutual interest along with requests for additional development assistance are evaluated. Technical and scientific exchange meetings are scheduled every two years alternatively in Beijing and Addis Ababa. Around nine meetings have so far taken place till 2012. In addition to JECC there are also other offices and institutions involved in Chinese developments assistance to Ethiopia, namely the office of the Prime Minster of Ethiopia, Ministry of Foreign Affairs and high ranking officials from the incumbent party, Ethiopian Peoples Revolutionary Democratic Front (EPRDF). Large scale loans and framework for agreements take place on a case by case basis, often at the highest political level. Inter-parliamentary and party-to-party meetings, mostly focused on EthioChinese bilateral relations, have also been conducted successively since 1991 . They have served as an important additional forum to further consolidation of the relations, and discuss on development experiences, state and party succession strategies (Hackenesch, 2011; Gedion, 2009).

Diverse agreements in technological cooperation, trade, investment and avoidance of double taxation between China and Ethiopia have enhanced the bilateral cooperation to a higher level. These are agreements for Economic and Technological Cooperation in 1971, 1988 and 2002; Trade agreements in 1971, and 1976, and Trade Protocols in 1984, 1986, and 1988; and Agreement for Trade, Economic and Technological Cooperation in1996 and Agreement for Mutual Promotion and Protection of Investments in 1988. In May 2009 the two countries signed an agreement to eliminate double taxation, which is boosting trade and investment. In the new millennium, SinoEthiopian bilateral ties have registered new progress within the context of FOCAC. The Forum has become the main institutional vehicle for shaping and managing China's cooperation framework with Africa across a range of technical, economic, and political platforms. The Forum was established by China in 2000 to be held every three years, to strengthen its economic ties with African States. Five highly successful forums were convened first in 2000, and followed by subsequent forums in 2003, 2006, 2009 and 2012. The Forum is the main institutional mechanism for Chinese development assistance to Africa and Ethiopia. In the forum China pledged to increased assistance to Africa as indicated in the successive forums.

In the last ten years, Chinese cooperation has become widely visible in Ethiopia, particularly in aid, trade and investment. The aid from China constitutes financial and technical assistance. The financial assistance is meant to implement projects and inclusive of both grants and loans. The second type of aid provided by China is technical cooperation which involves dispatching of medical teams and teachers, and offering educational scholarships for Ethiopian students to study in China. This trend is explained below under the sector of health and education. With regard to the first type of aid, financial aid, since the economic cooperation between the two countries started in early 1970s up until 2005, the Chinese government had extended to the government of Ethiopia an economic assistance in the form of interest-free loans which are estimated to be half billion RMB.

In the recent past, China has shown remarkable improvement in direct aid as loan to Ethiopia. Accordingly, since 2006 excluding the investment or commercial suppliers' credit loan to the telecom sector, China has committed 3.3 billion USD as a loan to Ethiopia with 46 development projects, out of which 475, 944, 967 USD and more has been allocated (Brautigan, Deborah, 2012). The above loans were allocated for the implementation of more than 30 projects such as Ethio-China Friendship Road, telecommunication upgrading, a large-scale vocational training institute equipped with advanced teaching facilities, Gottera Fly Over Road (Confusion road), Meskel Square to Bole Ring Road, hospital construction, sugar production, railway, telecommunication sector and other projects including Agricultural Demonstration Center (MOFED, 2012). China also built the new African Union Conference Centre with 200 million dollar in Addis Ababa and handed it over to African Union Commission (AUC) in January 2012. See Figure 1 on the trends of Chinese loans to Ethiopia from 2005 to 2012 (July) in USD.

Grant from China to Ethiopia is also on the increase. From 1995 to 2008 China gave 396 million RMB to Ethiopia, and from 2009 to 2010, China extended 124.6 million USD as a grant to Ethiopia. China has also handed over $\$ 800,000$ worth of food aid in 2009. In 2011 China gave 55.28 million USD as a grant to Ethiopia, one of its largest single gifts to a foreign country (China Daily/ANN, Aug 16, 2011). The above trends in loans and grants show the increasing rise of China as donor to Ethiopia. As the trends from 2005 to 2012 indicate, Chinese aid to Ethiopia is increasing dramatically. As far as the commitment to Ethiopia is concerned, China stands first in terms of bilateral aid. Yet in terms of disbursement from 2005 to 2012, UK stands first. But if we compare data of recent years on Chinese and UK's DFID loan, for instance, in 2011 China stood 


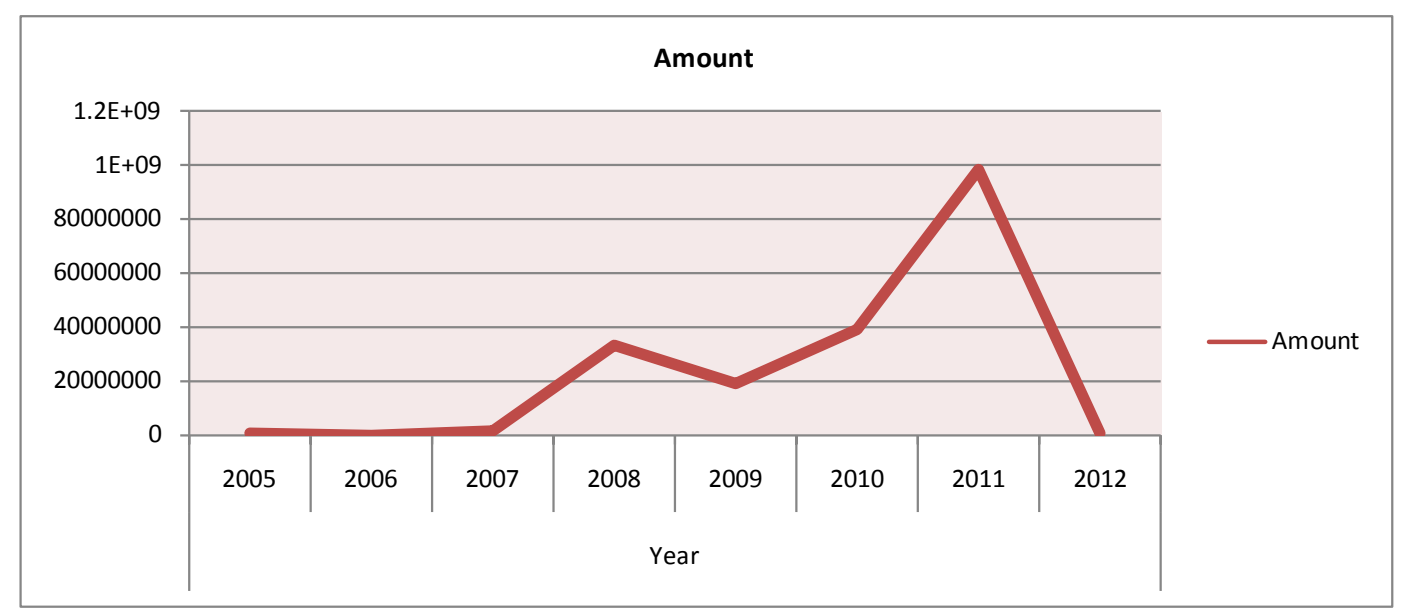

Figure 1.

Trends of Chinese Loans to Ethiopia from 2005-2012 (July) in USD; Sources: Ministry of Finance and Economic Development of Ethiopia.

first both in terms of commitment and disbursement of aid among bilateral donors. Hailemariam Desalegn, the then Ethiopian Foreign Minister and deputy prime minister, said in his briefing on loans and grants to the parliament, "In the development effort of Ethiopia, China is the first strategic partner to Ethiopia”. ${ }^{1}$

\section{Distribution of Aid by Sectors ${ }^{2}$}

In Ethiopia about 96\% of Chinese development assistance goes to such three sectors as energy generation and supply (52\%), transport and storage (31\%) and Industry (12\%). Out of this, $52.19 \%$ of Chinese development assistance in terms of commitment has been extended to energy generation and supply. They include building projects on hydro power, power transmission lines, solar power, wind power, marsh gas such as Aba-samuel Hydropower plant rehabilitation project (which provide 6.6 MW of electricity), Neshe civil and electro mechanical work contract; Fincha, Gedo-Gefersa power transmission, Beles-Bahrdar transmition, and also assistance for Ghibe III, Tekeze and others. This is followed by transport and storage that account for 31.13\% Chinese aid to Ethiopia including Addis Ababa-Adama road, Magenagna-Arat Killo and Menelick Hospital road; Bole-Meskel Square ring road and light railway among others. Industry constitutes $12.45 \%$ mainly targeted

\footnotetext{
1“China provided 500 million USD to 15 different projects in Ethiopia” The Report (The Amharic News Paper), August, 20 2011. Vol. 16, no.50, See also the reporter news paper (Amharic), 21 December 2011, Vol. 17 No 14, and The Reporter (Amharic), December 28, 2011, Vol 17 No. 15 available at www.ethiopianreporter.com

${ }^{2}$ The data on Chinese and Indian development assistance to Ethiopia was taken from MOFED of Ethiopia. Though the data indicated the overall commitment and disbursement of the development assistance from the two countries, the figures on the disbursement column are not updated for some reasons. Though some projects are completed and the aid committed is disbursed it is not included in the disbursement column. For instance, the comprehensive hospital-Trunesh Dibaba Beijing hospital and the agriculture demonstration centre were completed and started giving service yet the data from MOFED indicate only the aids committed. The reason MOFED official gave was that the report did not reach them. Accordingly, in this section and study for both China and also India, the author has used the overall China's and India's development assistance in terms of commitment to different sectors. Indeed, there is no major difference among the top sectors the aid directed both in terms of commitment and disbursement.
}

Mugher Cement Expansion Project-Mugher produce line and Mugher Cement Expansion Project-Tatek produce line whiles the remaining $4.3 \%$ goes to other sectors. See Figure 2 on trends of China's aid to Ethiopia by sectors (actual commitment) from 2005 to 2012 (July) in USD.

\section{Telecommunications Sector}

The main focus of China's infrastructure finance in the country has been the telecommunications sector. ${ }^{3}$ Zhong Xing Telecommunication Equipment Company (ZTE) has already started to upgrade Ethiopia's telephone system for four years since 2007 with a capital of \$1.5 billion commercial suppliers' credit. Further, the company is working on the delivery and installation of mobile-phone network equipment using Code Division Multiple Access (CDMA) technology; a high volume fiber-optic transmission line and the installation of 1.2 million mobile telephone lines in Ethiopia's capital Addis Ababa and eight other towns. In 2006-07 China agreed to provide financing for the Ethiopia Millennium Project to create a fiber-optic transmission backbone across the country and roll out the expansion of the cellular Global System for Mobile (GSM) network, with an estimated 8.5 million new connections. The project is financed under export seller's credit arrangements with the Chinese telecommunications operator ZTE for the supply of equipment to the Ethiopian national telecommunications incumbent (Interview with Ethiopian Telecommunication Corporation (ETC) Officials. 12/07/2012, 4-5 pm).

\section{Debt Reduction and Relief}

It is an important instrument to promote relations with African countries. In May 2007, Ethiopia and China signed a debt relief agreement in Addis Ababa amounting to US\$18.5 million. The agreement was signed by Mekonen Manyazewal and China’s Assistant Minister of Commerce Wang Chao 王超.

\footnotetext{
${ }^{3}$ In Chinese development assistance there is no clear distinctions between Aid, trade and investment. Ethiopian Ministry of Finance and Development (MOFED) classifies the concessional loan to telecommunication as an investment and the projects in telecommunication are not included as aid. However, according to Chinese definition of aid in the white paper, it can be included as aid.
} 


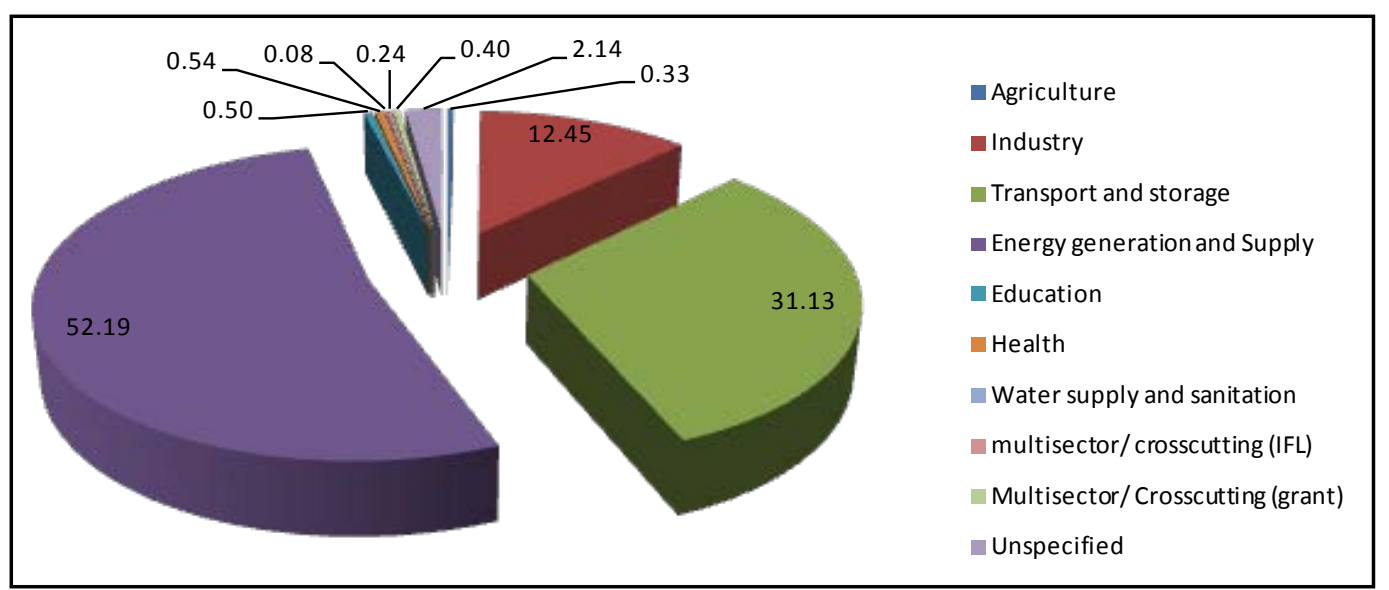

Figure 2.

Trends of China's aid to Ethiopia by sector (actual commitment) from 2005 to 2012 (July) in USD; Sources: Ministry of Finance and Economic Development of Ethiopia.

Chinese government also cancelled due debts of interest-free government loans that matured by the end of 2009. This creates the opportunity to utilize the resources to invest in other sectors of the economy like social infrastructure by investing in health and education.

\section{A Review of India's Development Assistance to Ethiopia}

Ethiopia and India have a long-standing relation due to their ancient civilizations and their proximity across Indian Ocean. During the Axumite Kingdom, Indian traders flocked to the ancient port of Adulis in the eastern part of Ethiopia and traded silk and spices for gold and ivory. However, modern EthioIndian diplomatic relations began after one year of Indian independence from British colonial rule, in 1948. To strengthen the bilateral relations, Emperor Haile Selassie visited India in 1956 and 1968. Subsequently, some Indian businessmen heavily invested in Ethiopia in certain industries like mills, cotton etc. The know-how, skills and tested power of organization efficiency of India have led to the foundation of the IndoEthiopian textile in Addis Ababa with three mills. Moreover, Indian businessmen have been serving the Ethiopian people by building hospitals, clinics, and other social amenities. The Gandhi Memorial Hospital, which was founded in 1955 and Harar Military Academy, which was established with the help of India are a cases in point (Ali, 1987: p. 41; Mathews, 1998: p. 15).

During 1974-1991, Ethio-Indian relations had deteriorated as a result of command economic system during the military regime. After 1991, there was economic liberalization both in Ethiopia and India following the collapse of Soviet Union, the main ally of the two countries. When EPRDF seized power in 1991, it immediately introduced liberal democracy and market-oriented economy. India also introduced grand economic reform under Narasimha Rao premiership in 1991. These coincidences of political and economic reforms in both countries have helped to further deepen political and economic cooperation between the two countries. In the economic arena, India has increasingly become one of Ethiopia's important partners, particularly in the area of trade and aid in supporting monetary aid (like line of credit) and non-monetary support (such as hu- man resource development and capacity building). There have been increasing Indian private investments in Ethiopia in almost all sectors of the economy. ${ }^{4}$ Indian teachers and professors, hired by Ethiopian Ministry of Education, have been providing helpful services especially in higher education through training young Ethiopian citizens in various fields of study. Recently, Indian aid to Ethiopia has also emerged as an important aspect of bilateral economic relations.

From the Ethiopian side, different government agencies are involved in relation to Indian development assistance. Chief among these are MOFED and Ministry of Trade. In 2002 an agreement on Cooperation in Micro Dams and Small Scale Irrigation Schemes was signed between the two governments. In 2007 agreements on Cooperation in the field of Science and Technology was signed. The same year, in July 2007, an agreement to establish a Joint Ministerial Commission (JMC) was signed between India and Ethiopia. The first meeting of the Joint Commission was held in New Delhi in December 2010. The Ethiopian side was led by Deputy Prime Minister and Minister of Foreign Affairs Hailemariam Desalegn. EAM led the Indian delegation. A Protocol on Foreign Office Consultations (FOC) was signed in July 2007. The first round of Consultations was held in New Delhi in March 2010. The Ethiopian delegation was led by Amb. Mahdi Ahmed, Director General for Middle East, Asia and Oceania in the Ministry of Foreign Affairs. JS for Eastern and Southern Africa led the Indian delegation.

In addition to the JMC and FOC there are other offices and institutions involved in Indian developments assistance to Ethiopia, namely the office of the prime Minster of Ethiopia, Ministry of Foreign Affairs and high ranking officials or ministries from different government ministries. There are also other councils between the two countries-though they are not directly related to aid-like Joint Trade Committee, Joint Business Council, India Business Forum etc.

Since 2006 there has been increased financial aid from India to Ethiopia. The government of India has committed more than US $\$ 1.2$ billion soft loans to Ethiopian government. The soft loan was extended by the government-owned Exim Bank of India. Specifically, India provided US\$65 million line of credit

${ }^{4}$ India is the largest investor in Ethiopia amounted to $\$ 4.78$ billion in various projects in Ethiopia, of which one billion is already in the pipelines. 
to support the Hageremariam Mega Zone for the construction of power transmission and distribution of rural electrification programme in 2006. This was the first Indian loan to Ethiopia (Singh, 2008). In 2007, India has extended additional USD 640 million, which is the largest line of credit made by the government of India to a single country in the world, to support expansion and building of new Ethiopian sugar industries. Both loans, one in 2006 and the other 2007, were provided with an interest rate of $1.75 \%$ with a 20 -year repayment period. At the end of the India-Africa Forum summit held in New Delhi in April $2008^{5}$, India decided to increase its provision of soft loans to Africa to USD 5.4 billion in a period of five years commencing from 2008. In the same summit, the Prime Minister Dr. Manmohan Singh had announced the Duty Free Tariff Preference Scheme for LDCs. Ethiopia was among the first countries that have acceded to the DFTP Scheme. As a follow-up of Joint Trade Committee (JTC) meeting, 41 experts of Leather Industries provided training to Ethiopian Leather Industries to enhance their capacities as part of a bench marking project which was funded by the Government of Ethiopia.

The second India-Africa forum summit took place in Addis Ababa, the Headquarters of the African Union on $24^{\text {th }}$ and $25^{\text {th }}$ May 2011. India announced its support to the development of a new Ethio-Djibouti Railway line by offering US $\$ 300$ million. ${ }^{6}$ In 2012 India provided \$500, million loans to Ethiopia for further sugar development expansion. Accordingly, Indian total credit line to Ethiopian sugar development was 1.24 billion dollar while the over all credit lines committed to Ethiopia has been 1.54 billion dollar. ${ }^{7}$ This makes Ethiopia among the top first recipients of Indian Lines of credit in the world. From this, it is possible to assume that in the future more loans from India will continue to flow to Ethiopia. The following Figure 3 indicates trends of Indian loans to Ethiopia from 2006 to 2012 (July) in USD.

\section{Distribution of Aid by Sectors}

In Ethiopia, $78.1 \%$ of Indian development assistance in terms of commitment and disbursement has been extended to sugar industry. The total cost of the project was indicated to be US $\$ 1.35$ billion. After the completion of such three projects, as Tendaho, Wonji/Shoa and Finchaa, Ehiopia will emerge as a major exporter of sugar. These projects will create huge employment opportunities and they are expected to create backward integration of the Ethiopian economy. In this regard, it seems that India is giving assistance where it has comparative advantage. As Official from EXIM Bank of India in Addis Ababa said, "India has been growing with sugar sector development and India does not want to import sugar from Ethiopia

\footnotetext{
${ }^{5}$ In this summit 14 African countries including Ethiopia participated. The summit adopted the "Delhi Declaration" and "African-India Framework for Cooperation" as a blueprint to substantially enhance Afro-Indian political and economic cooperation in the 21st century. For more information on Indian pledge to African countries on the summit and on the prior India-Africa business meeting see Naidu and Herman, 2008. "No 'Sleeping Walking' in Africa”, Global Dialogue, August 2008, 13(2): An International Affairs Review Published by Institute of Global Dialogue. P. 5.

${ }^{6}$ In the summit two documents namely the Framework for enhanced cooperation and the Addis Ababa Declaration were adopted.

${ }^{7}$ As of June 2012 the first top recipient of Indian lines of credit in terms of disbursement and not commitment is Sri Lanka with 1.2 billion USD followed by Bangladesh with USD 1 billion and Ethiopia with 705 million USD. See OECD, 2012. "Trade Related South-South Cooperation: India”, OECD Conference centre, Paris.
}

yet we wanted to replicate our experience in Ethiopia” (Interview with MOFED Authority, Indian and Chinese Desks, 12/06/2012, 3-4 pm, and 18/06/12, 4-5 pm). The second India-Africa Summit took place in Addis Ababa-where the Headquarters AUC are-on $24^{\text {th }}$ and $25^{\text {th }}$ May 2011. India announced its support to the development of a new Ethio-Djibouti Railway line by offering US\$300 million. However, negotiations are still on going on the type of railway that will be constructed. The remaining 3.89\% was disbursed to energy generation and supply. And $17.9 \%$ of the assistance was committed to transport and storage. India had given an EXIM Bank Line of Credit worth US\$65 million to Ethiopia for a power transmission and distribution project under the rural electrification programme in 2006. See Figure 4 on trends of India's aid to Ethiopia by sectors (actual commitment) from 2006 to 2012 (July) in percentage.

\section{Debt Reduction and Relief}

India has started giving huge loan to Ethiopia very recently, since 2006. It will be seen in the future whether it has a policy of debt relief for Ethiopia or not.

\section{The Impact of the Global Financial Crisis on China's and India's Aid to Ethiopia}

As many western governments and donors decrease their development aid due to aid fatigue and other factors like financial crisis, and governance conditionalities, many African states including Ethiopia are turning to China and India to finance their development projects. As Figures 1 and 3 indicated, the development assistance from China and India to Ethiopia has been increasing dramatically since 2008, which means that the financial crisis has no adverse effect on China and Indian development assistance to Ethiopia. Both China and India also pledged to increase soft loans they extended to African countries in the 2011 and 2012 India/China-Africa Forums. This shows how China and India have been the key players in driving the global economy out of recession, which will help Ethiopia and other African countries to mitigate the adverse effects of the global financial crisis, which in turn will creates opportunity for China and India to consolidate their roles in Ethiopia and beyond and promote their long term strategic interests. As the officials from MOFED indicated, "the amount of funding from China and India, particularly from China, is increasing as the financial flow from the west is decreasing as a result of the financial flow" (Interview with MOFED Authority, Indian and Chinese Desks, 12/06/2012, 3-4 pm, and 18/06/12, 4-5 pm).

\section{Comparative Analysis of Chinese and Indian Aid to Ethiopia}

China and India, as re-emerging donors, are not new to Ethiopia and Africa. Both countries have been providing aid to Ethiopia since Emperor Haille Sillasie's time and to Africa since the end of colonial period, at least as long as the West. However, unlike the case with western countries, the aid flow from both countries was very minimal until recently. Development assistance from both countries also emanated from their development experiences and has been based on the three principles of non-interference, solidarity grounded in shared 


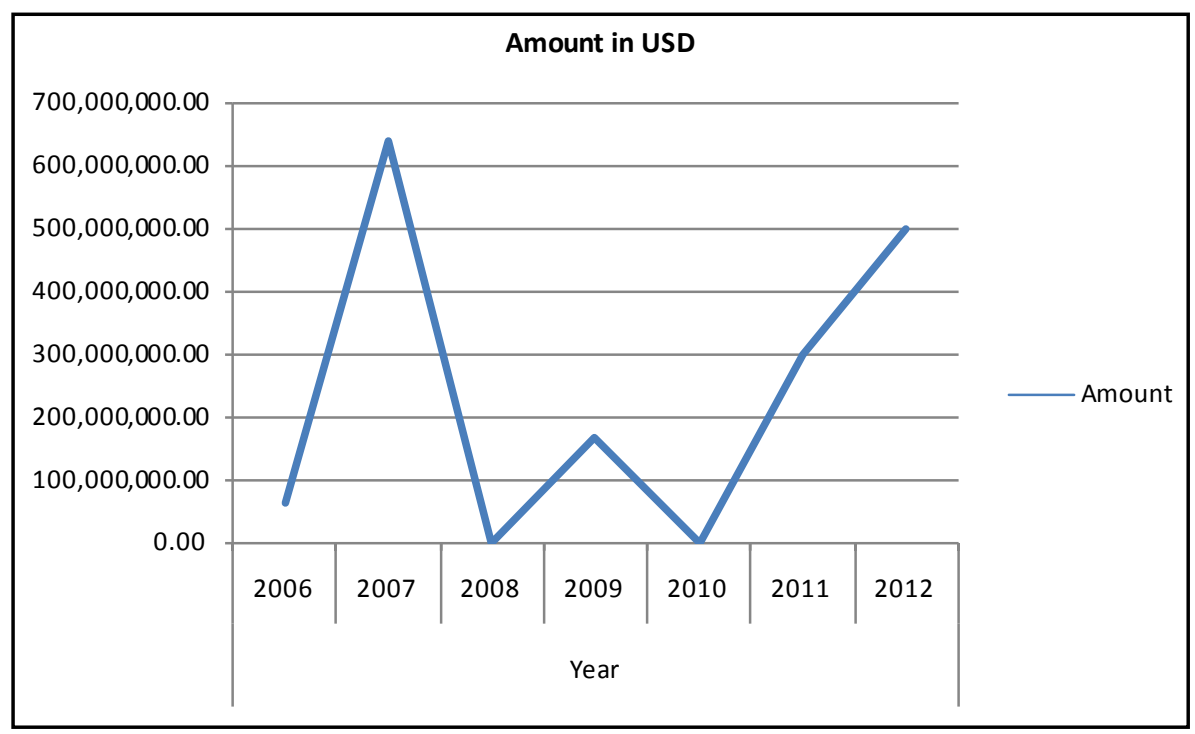

Figure 3.

Trends of Indian Loans to Ethiopia from 2006-2012 (July) in USD; Sources: Ministry of Finance and Economic Development of Ethiopia.

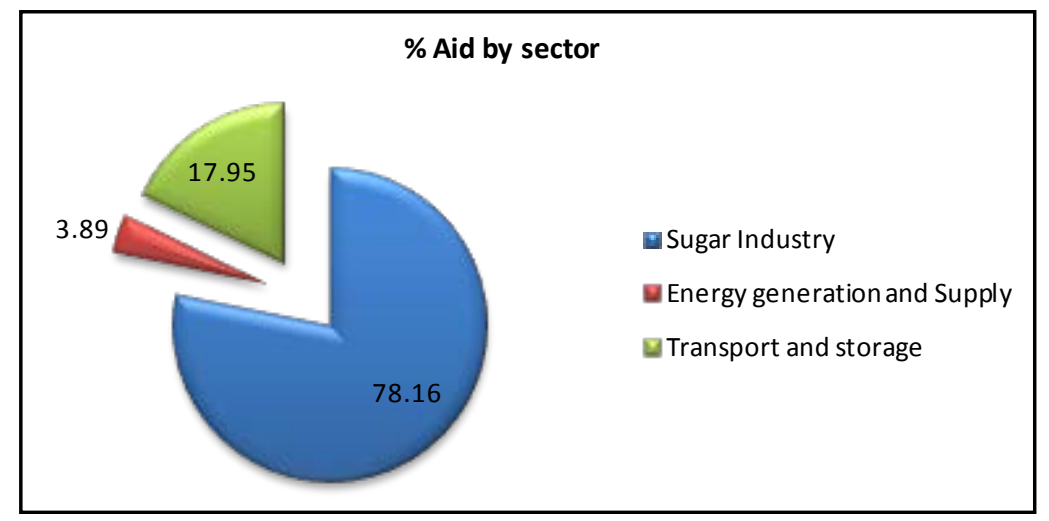

Figure 4.

Trends of India's aid to Ethiopia by sector by actual commitments (AC) from 2006 to 2012

(July) in percentage.

experiences, and equal partnership that brings mutual benefits. For instance, massive investment on road construction has been an important element for China's success in its reform and opening-up. As Brautigam rightly indicated with regard to a Chinese saying and its implication on their development assistance, "the Chinese say at home to get rich, build a road and so they focus their aid on infrastructure" (2011: p. 1). She also added that "Chinese believe agriculture is the foundation and industry is the leading edge and agriculture and industry have always been a big component of their aid and now their economic engagement” (Ibid).

This study found significant similarities between the aid practices of China and India in some important and inter-related respects. With regard to aid strategies in particular, both countries give monetary and non-monetary forms of assistance. Both countries are motivated by a combination of strategic and political interests as well as mutual benefit with commercial intent. In this regards, they do have similarity with traditional western donors in that their aid practices are tied with some conditionalities. Yet neither country has conditions of governance, democ- racy, and human rights. Meanwhile, both China and India have valuable contributions to make towards Ethiopia's development in the spirit of South-South cooperation, which needs to be understood in the context of the changing global development-assistance architecture (Naidu \& Herman, 2009: p. 147).

China and India, like Japan, both prefer to view its cooperation commitment as demand-driven i.e., upon the request of the recipient country rather than their own development priorities (which is typical of the aid from the West). Yet there are strategic considerations coupled with the ability of the recipient state to effectively utilize the aid for designed projects. The researcher interviewed both Indian EXIM Bank Official in Addis Ababa and Chinese Commercial Councilor. They both indicated that the development assistance was given principally based on, among other considerations, the request or interest of recipient states and the capacity of the recipient countries to disburse the aid. Both countries do have their own mechanism of channeling aid, especially on their own respective forums with Africa. However, specific African country has to make request to, and negotiate bilaterally with, China and India. And 
the said request and/or negotiation should be based on the strategic interests of the states to which they extend aid. In this regards, both China and India appear to have aspirations to become major political and economic forces in the world, Africa, and Ethiopia. Stronger economic and political relations with Ethiopia appear to be part of their strategy.

Chinese and Indian assistance is also characterized by relatively faster and less bureaucratic disbursement aid regime. Several African countries, including Ethiopia, are using this advantage. The decision making process in China is far more efficient than it is that in the West. Decisions and recommendations for investment are often directed by the government and they are able to meet requests from African countries faster than the traditional donors. As a senior UN expert put it, "If you want concrete things you go to China. If you want to engage in endless discussion and discourse you go to the normal traditional donors" (Busia, 2011). Hence, both countries have dramatically increased their development assistance to Ethiopia, especially since 2005. However, China has raised its political profile in Ethiopia by signing numerous co-operative agreements and making more arrangements for the exchange of high-level visits between Chinese and Ethiopian officials and party-to-party communications than does India.

To Ethiopia, China gives a high volume of monetary and non-monetary aid, which comes to Ethiopia in such a wide variety of forms as grants, interest free loans, concessional loans, and technical assistance. As the only country in Africa that has received support from all eight FOCAC policy measures, Ethiopia is not only the largest recipient of EXIM Bank loan but also a recipient of preferential and commercial loans from Chinese Development Bank (Interview with MOFED Authority, Indian and Chinese Desks, 12/06/2012, 3-4 pm, and $18 / 06 / 12$, 4-5 pm). India, on the other hand, has been also giving both monetary and non-monetary aids, but the amounts of their grants to Ethiopia are currently minimal. With regard to non-monetary aid, India has been providing technical assistance in capacity building, education and etc. As the current trend indicates, both countries are expected to increase their level of aid in light with their commitments at China/India-Africa summits of 2012 and 2011 respectively.

Neither China nor India gives loans or grants for general budgets and programmed aid for Ethiopia (Interview with Official of Chinese Commercial Centre in Addis Ababa, Ethiopia 28/06/12, 10-11:30 am, 14/06/12, 2:30-3:30 pm, 19/06/12, 11-12 pm). China, however, has been giving debt relief to Ethiopia not tied to any project or programme. For example, China cancelled a debt owed by Ethiopia and at the same time gave an interest free loan for different projects. There is hardly programme aid from either country except for the debt relief from China. In terms of aid commitments amongst the top nine aid providers to Ethiopia from 2005 to 2012 (July), China constitutes 41.77 percent while India constitutes 20.83 percent. And in terms of disbursement in the same time period, China constitutes 14.76 percent amongst the top nine bilateral aid donors to Ethiopia while India constitutes 21.87 Percent. Hence, in terms of aid commitments China is ahead of India while in terms of the speed of disbursement, India is a bit ahead of China. For more information please see Figure 5 on the top nine bilateral aid providers (actual commitments and actual disbursement) to Ethiopia from 2005 to 2012 (July).

Both countries monitor and evaluate their development assistance to Ethiopia. With regard to Indian LOC, it is monitored by a team member from Indian Embassy in Ethiopia and EXIM Bank of India based in Addis Ababa. The Ethiopian government with the consultants meets every one month and evaluates the projects and report to the Exim Bank of India quarterly. After completion of a project, a comprehensive report along with visual documentation must be submitted to the Ministry of External Affairs, Exim Bank and DEA, by the LOC recipient Government and Indian exporters. Where necessary, an independent agency may also be engaged to assess the performance of the LOC for the purpose for which it has been approved (Interview with EXIM Bank Official and Government of India above). On the other hand, with regard to Chinese aid, Chinese embassy, particularly the commercial councilor section of the embassy, monitors the Chinese aid projects. The Ethiopian government also approves the quality of the projects.

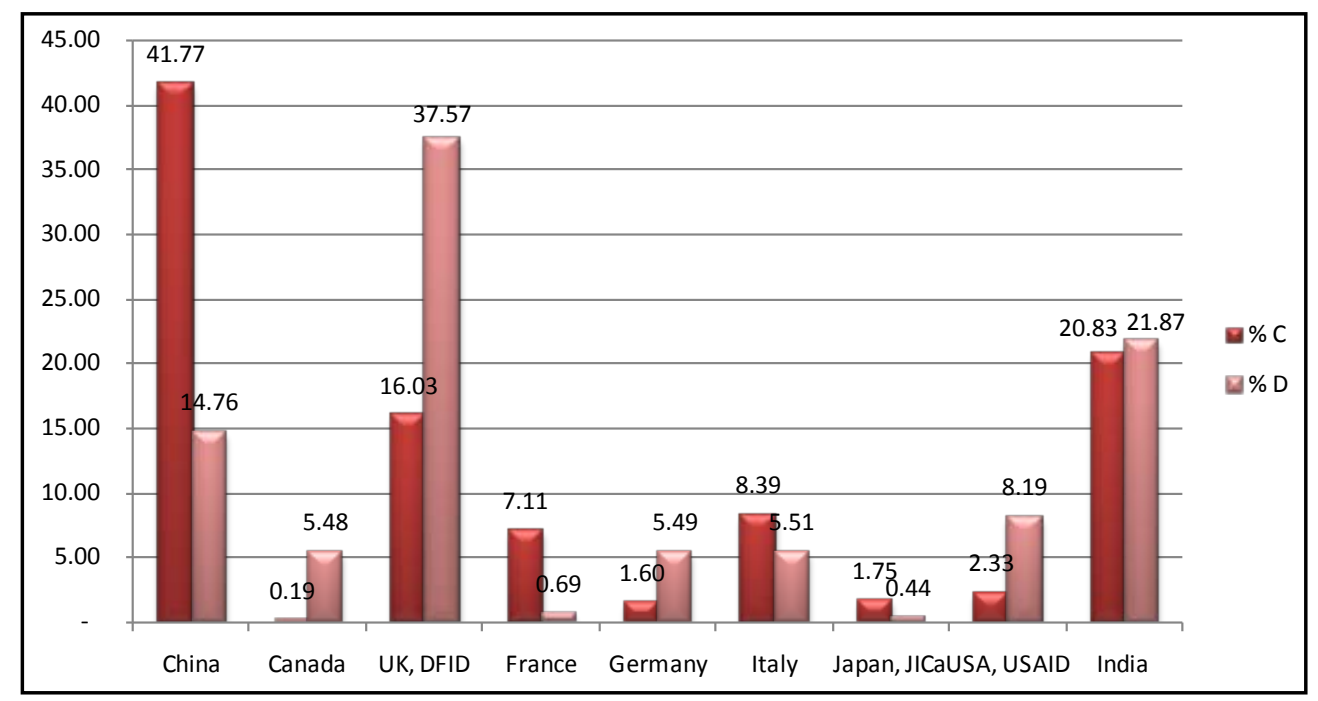

Figure 5.

The top nine bilateral aid providers by actual commitments (C) and actual disbursement (D) to Ethiopia from 2005 to 2012 (July); Sources: Ministry of Finance and Economic Development of Ethiopia. 
Besides other strategic considerations, both India and China also take into consideration the capacity of the recipient country to ensure proper utilization of the amount of loans granted to the recipient country. In our interview with the representative of both Chinese and Indian officials, Ethiopia is commended for having not only a development vision but also able bureaucracy that is capable of effecting large amount of development assistance.

Both China and India give scholarship for academic programmes with varying degrees. In addition, India offers technical training through the ITEC Division of the Ministry of Foreign Affairs. Information about specific courses is disseminated through ITEC to partner countries. Ethiopia is included on the list of ITEC countries. The Government of India funds the full cost of training for the selected candidates. Thus far, 325 Ethiopian were trained under this scheme.

Both China and India offer technical or non monetary assistance to different sectors of the economy and specific assistance in development activities. The $16^{\text {th }}$ Chinese medical teams consisting of 15 medical experts are devoted to medical service in Ethiopia. The second batch of medical equipment and materials were donated to Tirunesh Dibaba-Beijing Hospital, a hospital whose construction was funded by the Chinese government. China has also dispatched three groups of volunteers to Ethiopia for different services. With regard to education, the Chinese government built three completed primary schools in rural areas, and about two more primary schools are about to be built in Addis Ababa. Since, 2001 China has dispatched 89 teachers for TVET training to Ethiopia and constructed Ethiopia-China Polytechnic Collage. As earlier noted, India is also providing consultancy to the Ethiopian revenue, giving professional assistance to the leather industry and has shown willingness to depute experts in protocol and diplomatic training. As yet their assistance in soil testing and computerization of land record are pending. India is also supporting Ethiopia in tele-medicine and tele-education.

China and India, moreover, offer aid in the form of tariff exemption to some products exported from Ethiopia. During the 2003 China-Africa Forum held in Addis Ababa, the PRC delegates announced the special preferential tariff treatment program, which removed import tariffs on 190 different items including food, textiles, minerals, and machinery from twentynine African countries, including Ethiopia. It was implemented in January 2005. The number of export items that enjoyed preferential treatment increased from 190 to 440 during the 2006 China-Africa Forum held in Beijing. India also gave various trade-related initiatives to Ethiopia like duty free tariff preference scheme, cluster development Studies and various capacity building and technical assistance programmes. As a result, China's and India's bilateral trade with Ethiopia has risen dramatically, constituting 40\% of the total trade in 2012.

Debt relief, which ties aid to companies and labour, is a form of aid used by China but not India so far in Ethiopia. Since India has started giving huge loan to Ethiopia very recently, since 2006, it remains to be seen in the future whether it has a policy of debt relief for Ethiopia or not. India ties its loan for equipments to come from India, as a senior official from Exim Bank of India in Addis Ababa said, "India use this strategy as a Markey entry to the recipient country yet India does not oblige Indian companies and labour to come to the recipient country rather the project is open to competitive bid with some condition-the equipment must come from India.” The official said that out of the total money needed for the project, $75 \%$ was coming from India as lines of credit; earlier it was $85 \%$ while the remaining $25 \%$ come from either the recipient countries or elsewhere (Interview with Indian Exim Bank Official, Addis Ababa, Ethiopia as indicated above). Chinese development assistance to Ethiopia is also unique in using different channels from what India uses, such as party to party engagement.

However, the two donors' types of aid to Ethiopia not only complement each other but also complement that of traditional donors to Ethiopia, for the three donors-China, India, and the traditional donors-focus on different sectors of the economy, projects or programme. Whereas a substantial proportion of the development assistance of China to Ethiopia goes to energy generation and supply followed by transport, storage, and industry, that of India goes to sugar industry followed by transport, and then energy generation and supply. The traditional donors in Ethiopia, on the other hand, focused little attention on the aforementioned large scale projects given by China and India. Instead, they focused on programmed aid such as budget support, education, poverty reduction, and health care. This underlines the complementary nature between traditional development partners and emerging development partners. Indeed there are also competitiveness among the three donors, which creates policy space for negotiation and leverage for Ethiopia.

China and India differ from western donors in the terms and conditions imposed on aid recipients. China's only condition is the adherence to its "One China” policy. China continues to assert that there is one China that encompasses the mainland and the island of Taiwan and will not, therefore, give aid to any country that recognizes Taiwan as an independent country. As the White paper on China's African policy, 2006, indicates, the only three countries in Africa without diplomatic relations with PRC are Swaziland, Sao Tome and Principe, Burkina Faso. China also makes extensive use of input conditionalities, especially tied aid. Much of this is tied to the purchase of Chinese goods and services by Chinese companies, utilizing Chinese inputs and labour. As the experience in Ethiopia has shown, once the companies finished the project aid, they will remain in the country and compete for another bid with $25 \%$ - $40 \%$ of cost reduction. This has the effect of underbidding and outbidding local construction companies.

Another form of aid tying is the use of recipient country's resource to secure finance as loan or the Angola Mode as earlier noted. In this regard China is using sesame in Ethiopia as collateral. India also ties its aid to the purchase of Indian goods and services, a practice that observers have questioned, since India has refused to accept tied aid from others. India, like China, views development assistance as part of South-South cooperation, and therefore avoids political conditionalities that could be interpreted in the recipient's internal affairs.

With regard to corruption and governance conditionalities, both traditional and emerging donors like China and India do have rules that discourage corruption in their development assistance, yet neither seems to have rules as to when or how aid or development assistance should be restricted when a pattern of corruption characterizes an entire recipient government. The global regime is no better institutionalized with regard to the issues of governance conditionalities like democracy and human rights in which many bilateral donors apply these conditions inconsistently. As Brutigham argued "Neither the IMF nor the World Bank (nor the Chinese) apply conditionality over democracy or human rights” (2010: p. 36). With regard to cor- 
ruption, Chinese model of assistance is more effective and less prone to corruption, as the aid is - unlike the case with traditional donors-disbursed through state-owned corporations, which features paper accountability, especially the aid on capacity building (Muhumuza, 2012).

In sum, China's and India's aid to Ethiopia or Africa does not necessarily exhibit a new form of behavior. Rather it shows how re-emerging actors enter Africa's aid architecture. The behavior of the actors reveals that of the traditional donors who give aid with one hand and retrieve it through privileging their companies, equipments, labour, consultants, unfair trade practices and debt services. Where the two actors changed is to increase the leverage of Ethiopian government vis-à-vis the traditional and other emerging donors. In this regard, Ethiopia and other African countries need to see their own role in this relationship as less of a recipient and but more of a strategic partner that has something that China and India want (Naidu \& Herman, 2009). For more information see Table 1 on the comparative analysis of Chinese and Indian Aid to Ethiopia.

\section{Opportunities and Risks Involved in Chinese and Indian Aid to Ethiopia}

\section{Opportunities Offered to Ethiopia}

\section{Infrastructure Development}

The development assistance from China and India to Ethiopia is hailed as the answer to Ethiopia's key economic challenges, especially in the country's massive infrastructure deficit. The provision and availability of well developed infrastructure like transport, telecommunication, and power supply is key to development. Nonetheless, Ethiopia's infrastructure record is very poor and underdeveloped, which is often mentioned as an obstacle to the country's development and economic growth. The country has the lowest road density in Africa, the total road network is 33,297 km. Telephone and internet services are also very low by sub-Saharan standard, with only 8.6 landlines and 5.8 mobile phones per 1000 people respectively. Accordingly, under the Growth and Transformation Plan (GTP) from 2010 to 2015, the Ethiopian government aimed to enhance power projects from $2178 \mathrm{MW}$ to $10,000 \mathrm{MW}$ and boost infrastructure. For instance, Ethiopia aims to construct several railways, 5000 $\mathrm{km}$ of railway lines by 2020 and some $1808 \mathrm{~km}$ of it is expected to be completed by 2015 as part of the Growth and Transformation Plan (GTP) of the government from 2010 to 2015. The development of infrastructure requires capital, skilled manpower, technology, and efficient and fast delivery of services. The pace of local capacity is, however, very slow to meet the growing developmental needs of Ethiopia. In this regard the Chinese and Indian aid to Ethiopia is indispensable.

The Chinese development assistance has playing a crucial role in road construction, power sector and telecommunication sectors as noted above. Ethiopia also signed memorandum of understanding for hydro power potential general survey of Ethiopia with Hydro-China Corporation. In the transportation sector, currently over $70 \%$ road Construction projects in Ethiopia are carried out by Chinese construction Companies. In a similar vein, the Chinese telecom company ZTE is enhancing the country's communication capacity by providing telecom equipment. India is also emerging to be a major player in the Ethiopian economy, particularly in sugar development, infrastructure and agriculture sectors as indicated above. Recently Indian companies are undertaking projects in the power sector and sugar industry development. To support and promote regional integration India announced its support of the development of a new Ethio-Djibouti Railway line by offering US\$300 million. All in all the Chinese and Indian companies are playing a pivotal role in the infrastructure development of Ethiopia. Hence, the role of Chinese and Indian development assistance is indispensable for Ethiopia, as they are bridging the local capacity gap with relatively better financial capacity, experience, good quality, better technology, and efficiency. This in turn facilitates investment and contributes to the country's development. This has positive effects on productivity and reducing poverty. These strategic investments will help Ethiopia to sustain its impressive economic growth rates. As officials from MOFED indicated "There is more convergence than divergence of Chinese and Indian development assistance to Ethiopia since they are huge giving assistance in line with the development priorities of the country" (Interview with MOFED Authority, Indian and Chinese Desks, 12/06/2012, 3-4 pm, and 18/06/12, 4-5 pm).

Table 1.

Summary of comparative aid engagements between China and India to Ethiopia; Source: Compiled and analyzed by the author.

\begin{tabular}{|c|c|c|}
\hline Issues for comparison & China & India \\
\hline Ownership/Nature & Ethiopian priorities, demand driven & Ethiopian priorities, demand driven \\
\hline Conditionalities & $\begin{array}{l}\text { Minimal-One China policy and no governance strings } \\
\text { attached }\end{array}$ & No governance strings attached \\
\hline Tying & $\begin{array}{l}\text { China ties its aid to using Chinese companies and } \\
\text { labour, procurement of materials from China }\end{array}$ & $\begin{array}{l}\text { Procurement of materials from India and } \\
\text { Consultants }\end{array}$ \\
\hline Sectors focused (the top three) & $\begin{array}{l}\text { Energy generation and supply followed by transport } \\
\text { and storage, followed by Industry. }\end{array}$ & $\begin{array}{l}\text { Sugar Industry followed by Transport and energy } \\
\text { generation and supply }\end{array}$ \\
\hline Projects given by both countries & $\begin{array}{l}\text { In addition to the above three, tariff exemptions, other } \\
\text { types of training, scholarships, and technical assistance }\end{array}$ & $\begin{array}{l}\text { In addition to the above three, tariff exemptions, } \\
\text { other types of training, scholarships, and technical } \\
\text { assistance }\end{array}$ \\
\hline Unique features to each donor & $\begin{array}{l}\text { Debt relief and China ties its aid using Chinese } \\
\text { companies and labour, Preference for grandiose and } \\
\text { prestigious projects, Cooperates through different } \\
\text { channels like part to party relations }\end{array}$ & - \\
\hline Neglected area/s & Budgetary support, programme aid & Budgetary support, programme aid \\
\hline
\end{tabular}




\section{Alternative Aid Partners}

Chinese and Indian increased economic assistance prompted more policy options to Ethiopia and other African countries vis-à-vis the traditional donors by giving the country more alternative development partners. The coming of China and India to Ethiopia also promoted the attention of other emerging powers like South Korea, Turkey, Iran, and the Arab Countries. The lack of strings attached with aid from both countries is also welcomed by Ethiopia. China's "business is business” approach is welcome in comparison to with western aid providers who often link their contributions to the changes in the Ethiopian legal and political structure, and to the adherence to human rights and good governance norms. As the late Prime Minister Meles Zenawi of Ethiopia pointed out that "India, like China, has been a most dependable and generous partner and it has always offered a relationship based on mutual respect and mutual benefit” (Ministry of Foreign Affairs of Ethiopia, 2012: p. $1)$.

\section{Access to Market through Tariff-Free Exports}

In order to facilitate the integration of the poor countries into the global trading system, China and India launched a Duty Free Tariff Preference (DFTP) scheme for the least-developed countries (LDCs) at the occasions of the first and second FOCAC in 2003 and 2006, and the first India-Africa Forum in April 2008 and India-Africa trade ministers in 2011. With the aim of expanding LDC exports, this scheme offers duty-free and tariff preference market access to goods and services originating from the LDCs. This initiative from China and India has enhanced Ethiopian export to China and India. Currently $40 \%$ of Ethiopian trade is with China and India. China and Ethiopia had an average annual increase of 36\% from 2000 to 2011 and exceeded $\$ 1$ billion for the first time in 2008. In 2009, China became the first largest trading partner of Ethiopia and since then exports from Ethiopia to China have increased over 200\%. Likewise the trade relationship between India and Ethiopia is increasing dramatically. As China's minister for commerce indicated, the trade between China and Ethiopia will reach US\$3 billion by 2015 (Kone, 2011). Ethiopia and Indian bilateral trade is also expected to reach 1 billion USD in 2015 (Embassy of India, 2011). Thus, Chinese and Indian trade relations with Ethiopia are breaking the hold the West had with Ethiopia over centuries. However, the balance of payment is not dissimilar from Ethiopia's trade relations with the West.

\section{Investment through Concessional Loan and CAD Fund}

Chinese and Indian development assistance is often delivered as part of a larger package of investments and trade deals, blended with much larger non-concessional loans and export credits. In the past four to five years Indian and Chinese companies, as the second and the third largest foreign investors to Ethiopia next to Saudi Arabia, are generating lots of employment opportunities. Especially China through CAD fund has invested around 2 billion dollars within the last four years, which is promoting Chinese investment in Ethiopia in infrastructures, agriculture, and other sectors, with particular interest in the manufacturing industry in Ethiopia. The fund has already invested in four big projects including glass factory, leather processing factory, cement plant, and a four-star hotel. Thus the investments from India and China have created huge permanent and temporary employment opportunities for Ethiopian citizens. For instance, Huajian Group of China, a shoe-manufacturing firm, has invested in Ethiopia and employed more than 800 workers and produces over 2000 pairs of shoes per day for export valued at US\$1 million per month.

\section{Human Resource Development}

Since the 1980s, the Chinese government has started to grant around 10 scholarships to Ethiopian college students for their study in China. Since 2001, the Ministry of Education of China has dispatched 89 teachers for TVET training to Ethiopia. Ethio-China Polytechnic College aided by China has been in operation for more than two years and 10 teachers dispatched by the Chinese Government have joined the running of College (Interview with Mr Yong, the media liaison official of the Embassy of China Embassy. 19/07/12 1:30-2:30 pm). At present, the Chinese staff employed by the Ethiopian side have been engaging themselves in the management of the institute. In November 2004, the Ministries of Education of the two countries signed an agreement for bilateral educational exchange and cooperation. From 2005 until now, there are about 1000 people from Ethiopia participating over 400 training courses held in China including bachelor, masters, and doctorate degrees programs. In addition to scholarships given to Ethiopian students, China aided more than 700 multilateral and bilateral training programs in short-term or long term for Ethiopia since 2006, covering various areas such as economy, trade, agriculture, forestry, cultural, medical, environment protection, telecommunication, public administration, sciences, and practical technologies, etc. And more than 1500 officials and management personnel have undergone training by participating in these programs to enhance the self development capacity of Ethiopia. Ethiopia is also the first country in Africa to which China sent its volunteers (Interview with Official of the Chinese Commercial Centre, Addis Ababa, Ethiopia 07/14/2012)

To promote cooperation for capacity building, since 1969 India has kept making available the services of experts in various fields to Ethiopia under the ITEC programme. The cooperation under this arrangement cross cuts different sectors. In 2007-08, the number of training slots offered by India was 25 . There has been a steady increase in the number of training slots offered by India. From 2009 to 2011, 300 more training slots were offered by the government of India and were fully utilized by Ethiopian governments. The pan African e-Network project was launched in Ethiopia in July 2007. The Tele-Education Centre at Addis Ababa University and the Tele-Medicine Centre at the Black Lion Hospital in Addis Ababa are altogether worth \$2.13 million and offered as a grant. The Central Leather Research Institute and the Footwear Design and Development Institute, both from India, have been cooperating with the Ethiopian Leather Development Institute to raise quality standards in Ethiopian tanneries and leather factories. A 41-member team of Indian professionals, comprising of representatives from the two institutions and also from the leather industry, arrived in Ethiopia in March 2010 for a six-month project. The value of the contract, which is being financed by Ethiopia's development partners, was approximately $\$ 1$ million. The contract has subsequently been extended for another six months for a value of $\$ 0.8$ million.

Currently, Indian government is providing consultancy to the 
Ethiopian Revenue and Customs Authority to support implementation of WTO customs evaluation. Initiated in October 2010, the assignment is expected to be completed by February 2011. Indian army is also training, and writing the manual for, the Ethiopian Army. The government of India, in response to Ethiopian requests, indicated its willingness to depute experts in protocol and diplomatic training. Requests from the Ethiopian side pending with India are for the services of experts in soil testing and computerization of land records. An agreement for Programme of Educational Exchange was signed between the two countries in 2007. In April 2008, India doubled to 40 the number of scholarships offered to Ethiopian students for university studies in India under ICCR programme. The Ethiopian Government offers some 350 scholarships to their nationals for university studies in India every year. The entire cost of $\$ 2.13$ million was borne by the Government of India as a grant. TCIL is the implementing agency of the project in all countries of Africa, including Ethiopia.

\section{Opportunities for China and India}

\section{Economic Benefits}

As noted earlier, both China and India are getting diverse economic benefits because of their development assistance or investment to Ethiopia such as market potential for their products tied to loans, promotion of trade, profit-earning of hard currency for their companies, and employment opportunity for Chinese citizens. Ethiopia could be a commercial launch pad for Chinese and Indian companies. The two Asian countries are also interested in a market for their exports that will expand along with the rapid growth of Ethiopia's economy. A significant portion of China and Indian aid activities in the areas of transport, power, industry, and telecommunications appears to fall within the scope of aid for trade, and comes as a potential source of materials - including oil-in the near future. As Mathews rightly indicated, "India is evidently excited by the raw materials that Africa has to offer as well as the 900 million hectares of underutilized arable land. Of all the Africa markets, India is showing most interest in the agricultural, mining and manufacturing sectors" (Mathews, 2011).

As an official from Chinese commercial councilor in Addis Ababa also said, "Ethiopia is an important project contracting market for China. The projects contracted by Chinese enterprises involve many areas such as roads and bridges, electricity, railways, telecommunications, house building, municipal construction and others. By the end of 2011, the total amount of contracted projects was $\$ 10.9$ billion. In 2011 alone the amount of contract signed was $\$ 3.3$ billion" (Interview with Official of Chinese Commercial Centre in Addis Ababa, Ethiopia 28/06/12, 10-11:30 am, 14/06/12, 2:30-3:30 pm, 19/06/12, 11-12 pm). The total Chinese assistance to Ethiopia from 2005 to 2012 was around 3.3 billion, out of which, the total amount of contracted projects was $\$ 10.9$ billion by the end of 2011. This is the amount China pledged for concessional loan in the 2009 FOCAC or it is half of the amount of concessional loans pledged at the 2012 FOCAC. The official also noted that "Chinese investment in Ethiopia is developing rapidly." Chinese investment involves industrial park, manufacturing, assembly of mechanical, electrical products, building materials, energy, mining, agriculture, and other Fields. China-Africa development Fund (CAD Fund) set up office in Ethiopia, and invested in the Han- som Glass Factory, Eastern cement plant, China- Africa leather processing plants, and other projects. Lifan Motors, Noah Textiles, Hansom Glass and Panshi Cement become the wellknown brands in Ethiopia. China-Africa economic and trade cooperation Zone-Eastern Industrial Zone in Ethiopia plays an active role in the investment promotion of Chinese enterprises to Ethiopia. Recently twelve Chinese enterprises have entered the park and three have been put into operation.

During the last few years, Indian companies have also won various government contracts in Ethiopia against tough international competition. Indian companies from public and private sectors have secured several contracts in the infrastructure sector, including consultancy works, in roads, power, telecommunications, water resources, and cement production. IRCON and M/s SMS Infrastructure have secured contracts in road construction. Likewise, RITES, International Consultants and Technocrats (ICT), Consulting Engg. Services, Span Consultants, LEA Associates have secured contracts in road studies and consultancy; KEC International, BHEL, Jyoti Structures, IRCON, Kalpataru Power Transmissions and Gammom India in power transmission, distribution and sub-stations; TCIL in telecommunications; WAPCOS and ICT in feasibility studies for micro dams and irrigation projects; and ACC and HOLTEC in consultancy for expansion of cement production. India is also the largest investor in Ethiopia ahead of China with its investments amounting to $\$ 4.78$ billion in various sectors in Ethiopia, principally in agriculture, steel, blanket, pharmaceuticals, and etc, of which one billion is already in the pipelines (Embassy of India, 2012).

\section{Strategic Diplomatic Importance: As the Seat of AU, UN Agencies}

China and India are also using their development assistance to promote their political and diplomatic interests abroad. A poor, landlocked nation, Ethiopia currently lacks the vast natural resources that have drawn China and India, though in the near future the prospect for oil is high, which enhances the development assistance to higher level. Yet Ethiopia plays an important role in African politics because of its strategic location in the region as the seat of a continental political body like the African Union and other agencies of the UN as well as World Bank and IMF. Ethiopia is the source of the Blue Nile; it is the meeting ground between largely Muslim North Africa and the Christian south. Hence, Ethiopia has become a focus of China's and India's wider ambitions in Africa and the changes it signifies for the region. In this regard, the late prime minister, Meles Zenawi helped India's relations in Africa (Bagchi, 2012). The Ethiopian government also played a major role in the creation of FOCAC in 2000 from the Africa side, and the second FOCAC was held in Addis Ababa in 2003. As CPPCC National Committee Chairman, Jia Qinglin 贾庆林 said “Ethiopia is an influential country in Africa ....and active promoter of FOCAC... and made outstanding contributions to promoting the development of China-Africa friendly relations and cooperation, which the Chinese side highly appreciates”(China Embassy in FDRE, 2012). China in return among others constructed a new conference center for the African Union, which comprises a 99.9-meter-high office building and a 30-meter-high conference hall with a vault covering 11.3 hectares. And its cost, which is worth 200 million USD, is fully covered by the Chinese Gov- 
ernment.

\section{Winning Diplomatic Support at the International Level}

Both countries, by offering aid without political conditions, presented attractive alternative to conditional Western aid to Ethiopia, and gained valuable diplomatic support to defend their international interests. For instance, India and China wants to win Ethiopia's diplomatic support in the United Nations and other international and regional forums, since Ethiopia has geopolitical influence in the region. India stands for reform of global political and economic institutions, including the UN Security Council. As Prime Minister Manmohan Singh told the African leaders at the 2011 India-Africa Summit quoted in Mathews, "The global institutions of governance are outmoded and are working under stress. We, therefore, need a new spirit of solidarity among developing countries". And the Prime Minister plea for the AU counts on Indian request for the UN Security Council seat (Delhi Declaration India-Africa forum Summit, 2008, 2011; Mathews, 2011).

China also needs diplomatic support from African countries including Ethiopia for its policy on Taiwan. Ethiopia is also a key partner to China in regional and international issues. As indicated in the White Paper on China's African Policy, "China will strengthen coordination with Africa in the UN and other multilateral systems by supporting each other' just demand and reasonable propositions". As Mao Zedong also put it, "We were brought back into the United Nations by our black African friends" (Li Anshan, 2007). In 2007, "Ethiopia in collaboration with other African countries prevented a resolution censoring Chinese human rights records at the UN Human Rights Commission. In 2006, the Ethiopian parliament passed a resolution to support China's Anti-Secession law. This provides China either the legal basis to take military action against Taiwan in case of unilateral declaration of independence" (Hackenesch, 2011). China in quid pro quo helped the Africa bloc at the UN that enabled African Secretary Generals to lead from 1992 to 2006.

\section{Risks of China's and India's Development Assistance to Ethiopia}

\section{Tied Aid}

Both India and China tie aid. Though the two emerging economies do not have governance related strings, they tie aid with other economic and diplomatic conditions. For instance, the variety of loans from China are tied to using Chinese companies and procurement of materials from China and diplomatic conditions, e.g., 70\% construction and civil engineering to be awarded to Chinese companies, which adversely affects wider spillover effects on local economies, job opportunities, and wider knowledge skill transfers. This has underbidding and out bidding effects on local companies because Chinese companies do have $20 \%$ - $25 \%$ and sometimes $40 \%$ of cost reduction when they compete for bid. The One-China policy is also another diplomatic condition to extend Chinese development assistance to African countries. The same can be said of Indian aid except labour. India tied its loan as an entry point to its private companies. However, as indicated in Paris Declaration on effectiveness of aid, tying aid is one of the main causes of its ineffectiveness. In this regard, re-emerging donors like China and
India needs to confirm commitment to Paris Declarations by untying their development assistance; and Ethiopia should negotiate to maximize the benefits and minimize the losses from the development assistance. As Officials from MOFED indicated "Ethiopia is losing a lot by trade ties with both China and India as the balance of payment is extremely unfair towards the latter countries, which is partly as a result of lack of competitive national companies. Therefore, the government should be able to protect infant industries" (Interview with MOFED Authority, Indian and Chinese Desks, 12/06/2012, 3-4 pm, and 18/06/12, 4-5 pm).

\section{Monopoly and Fear of Over-Dependency}

The other risk closely following from tied aid is monopoly and fear of over-dependency. Some of the Chinese and Indian projects are not commercially won through competitive bids. Instead, they are financed through tied aid. For instance, ZTE is providing $100 \%$ telecom equipment for ETC, which is the sole telecommunication operator in Ethiopia. Such a trend is in turn feared to create over dependency; because once the existing telecommunications equipment is replaced by Chinese new equipment and become operational it would be very difficult to use other spare parts and technology like Nokia, since the Chinese technology is not easily compatible with others. This in turn will sustain Chinese monopoly in this sector. The Chinese monopoly could endanger Ethiopia's interest in the long run, since it could enable China to gain political influence, which often opens the doors for commercially or strategically more attractive business in other sectors too. It could also become very difficult to measure their efficiency and quality. Moreover, this development discourages the competitiveness and efficiency of developing infant local companies. Hence, the Ethiopian government needs to be cautious about such a dangerous trend.

India like China is using foreign aid as one of the instruments to achieve its foreign policy objective of encouraging Indian public and private companies in profitable investment and carry out development projects supported by Indian government in African countries including Ethiopia. Rural electrification and sugar project in Ethiopia have been undertaken by Indian company through tied Indian aid. Impressed by the success of China, India appears to replicate aid-for natural resource strategy in its relations with African countries. For instance, in West Africa India has offered soft loans amounting to US\$1 billion to finance power and infrastructure projects in exchange for oil exploration rights and supplies (Ramachandran, 2008). India offered Ethiopia huge soft loans as indicated above for expansion and building of electric power infrastructure and sugar industry provided that the technology comes from India. This creates long term dependence on Indian technology.

\section{Lack of Transparency and Corruption}

Mutual accountability and transparency is one of the partnership commitments of the Paris Declaration and Busan Outcomes Documents, which are imperatives to promote accountability between donors and recipient countries, and other concerned by knowing who funded what and for whom, what projects are funded for what purpose and where. Hence, transparency is important to improve effectiveness of aid and reduce corruption. However, lack of transparency in aid and finance agreements is another challenge of the development assistance 
coming from China and India to Ethiopia. There is some information on Chinese and Indian Aid at general level because of their pledge at forums either China-Africa or India-Africa forums yet there is apparent lack of information at a country level. In addition, both are amongst non-DAC donors including India, Brazil and Russia that do not report their aid. Chinese and to some extent Indian aid are also tied to grants and take place at executive levels at the stage of negotiations. The side-stepping of institutions promotes corruption and undermines the good governance initiatives in Africa. As corruption is one of the top governance and development challenge of Ethiopia and Africa. Africa is loosing 150 billion USD because of corruption according to AU 2003 report. However, except grant, the Chinese almost never disburse any actual money through their loans to the recipient governments. Rather they transfer to their companies and sub contractors authorized by the recipient country, which helps to avoid grand corruption but not petty corruption. The same can be said of India to some extent.

It is important to note that both traditional and emerging donors like China and India do have rules that discourage corruption in their development assistance or aid. Yet neither seems to have rules for when or how aid or development assistance should be restricted when a pattern of corruption characterizes an entire recipient government. The global regime is also not well institutionalized with regard to issues of democracy and human rights in which many bilateral donors apply these conditions inconsistently. As Deborah, confessed "Neither the IMF nor the World Bank (nor the Chinese) apply conditionality over democracy or human rights” (2010).

\section{Insufficient Technological Transfer}

Chinese companies are criticized for excessively employing Chinese professionals. With few exceptions, Chinese companies do not also place locals in key managerial posts; they employ locals for the administrative and low paid jobs like clerks, secretaries, guards etc. Some even say these positions are left for the locals because the companies are not allowed to bring their own non-skilled employees. This in turn, hampers the local employees from acquiring new technologies and managerial skills. As a Chinese scholar put it, “...Chinese entrepreneurs are accustomed to bringing laborers from China and most management positions are filled by Chinese nationals. From an economic perspective, it is more efficient and convenient for Chinese entrepreneurs to recruit skilled workers in China than to train local workers” (Li Anshan, 2007: p. 81). Moreover, almost all of the Chinese companies engaged in big projects conduct researches in the headquarters rather than basing it in Ethiopia, which in turn discourages the intended technological transfer. Most of the materials used by Chinese and Indian companies are imported from them, which therefore excludes and discourages possible local suppliers. The same can be said about India.

\section{Chinese Development Model}

Chinese and Indian developmental model indicated the role played by the state in regulating the economy, guiding the market, and reducing poverty while registering continuous economic growth. However, Chinese and Indian development assistance generally comes with no strings attached; but the lack of requirements for better governance or social programs would mean that the availability of Chinese and Indian aid may undermine African governance. Some African states including Ethiopia attempts to define the "developmental states" partly as their response to East Asian and more particularly to China's economic growth success. Chinese model of development showed economic growth without civil liberties or participatory democracy. The development model also discredits the notion that an autonomous civil society is central to development. This may adversely affects the democratization process in Ethiopia.

\section{Debt Sustainability}

China is providing commercial loans to African nations including Ethiopia that have just received debt relief, thereby sometimes forcing them back into a cycle of mounting indebtedness. However, China defends such allegations by its policy of debt cancellations and debt rescheduling based on indebted countries request; yet this might motivate Ethiopia to continue borrowing and seeking of Chinese loans, which reinforces new debt cycle. Besides, this scheme is only available for countries that have continued diplomatic relations with China (Brautigam, 2010). On the other hand, the government of India argues that Indian aid is mutually beneficial because the aid is not linked to India's domestic demand. For instance, India supports sugar industries to strengthen Ethiopia's competitiveness in global sugar market. It is not for the purpose of importing it from India, which is one of the major exporters to the world market. However, despite the good intention, if Ethiopia is not able to pay back the loans, it may serve as political leverage for India to advance political and economic interest as the West has been doing. In addition, it may exacerbate the debt crisis the country is currently facing. In this regard, Ethiopia needs to prepare a strategy to reduce dependence on continued assistance from China and India and also other donors incrementally.

\section{Conclusion and Policy Recommendations}

\section{Conclusion}

The analysis of this study showed clearly that the potential positive impact of Chinese and Indian aid on Ethiopia is significant yet not bereft of challenges. Development assistance from China and India has offered benefits to Ethiopia for infrastructure development. For instance, it has provided alternative development partners especially at this time of financial crisis, access to market through tariff-free exports, new investments, human resource developments, and employment creation, and relevant development experiences. This helps Ethiopia to sustain its impressive economic growth and development. Both China and India are proactive in their engagement with Africa and Ethiopia, and do have African policies, which they are implementing. There are also several factors forcing China and India to provide development assistance to Ethiopia. Consequently, both countries stand to benefit from increasing involvement with Ethiopia. Economically, there are emerging opportunities in infrastructure projects in roads, power, telecommunications, water resources, gas exploration, wind-based energy, hydropower projects, sugar industry, machinery and engineering goods, and general trade. The two re-emerging donors are also benefiting politically and diplomatically in terms of their aspirations to be regional and global leaders. Both are reemerging donors in Ethiopia yet China's development assistance is comprehensive by providing variety of aid as noted above. As the current bilateral cooperation indicates both 
Ethiopia and China are said to be in their "honey moon".

The two donors' types of aid to Ethiopia complement each other and they also complement the aid from traditional donors to Ethiopia. The three donors-China, India, and the traditional donors-focus on different sectors of the economy with their individual projects or programmes. The traditional donors in Ethiopia focused on programmed sector like budgetary support, and offered support to other sectors like education, health care, poverty reduction through protection of basis services. In addition, they also focused on humanitarian aid as well as promotion of good governance, human rights, and democracy. Of course there is also competitiveness among the three donors, which creates policy space for negotiation and leverage for Ethiopian government. Chinese and Indian assistance is also characterized by relatively less bureaucratic, and fast disbursement aid regime. Several African countries, including Ethiopia, are using this advantage. The decision making process in China is far more efficient than it is in the West. Decisions and investment recommendations are often directed by the government, and they are able to meet the requests from African countries faster than the traditional donors did. But the development assistance from these two countries is not bereft of such challenges as tying aid, monopoly, fear of over-dependency, lack of transparency, corruption, insufficient technological transfer, Chinese development model, and debt sustainability. Hence, the following interventions are crucial and they could be implemented unilaterally by African countries like Ethiopia and bilaterally through the joint effort of the two:

\section{Policy Recommendations}

\section{For Ethiopia and other African Countries}

1) Developing a good understanding of Chinese and Indian approach to aid. As indicated from the outset of this study, both Chinese and Indian aid came under the influence of certain commercial intention and it is more of development investment than pure aid. This enables Ethiopia to better coordinate and shape its own agenda vis-à-vis those of China and India. In this regards, it is important that projects should be fully agreed upon by both Ethiopian government and the governments of the donors, namely China and India, prior to implementation for win-win effects;

2) Ensuring quality of projects: The quality of the projects that are fully funded by the Chinese and Indian governments, occasioned by uncompetitive bidding practices, and carried out in unsafe production method should be evaluated by independent experts as the informants from different government ministries like Road Authority, telecommunications among others mentioned. Unsafe working conditions in China lead to the death of 320 Chinese people each day (Li Anshan, 2007: p. 85). Hence, Ethiopia should monitor and follow up the quality of the services and products provided by Chinese and Indian companies. For those high-tech equipments and services provided by Chinese and Indian companies, Ethiopia needs to hire competent professionals and consultants to check on the quality. Ethiopia should also encourage and support local companies to enhance their capacity. There is a good move in this regard; Ethiopia in the GTP of the country from 2010 to 2015 reserved some of the infrastructure development to local companies;

3) As for ownership, management and incremental leveraging of the aid flows to Ethiopia, Ethiopian government must strategise and negotiate for win-win situation. Specifically, they should do so for greater national economic effects by negotiating for quotas for employments of local professionals and non-professionals, technological transfer, and subcontracting to local suppliers. So as to make the relations mutually beneficial. For instance, China and Korea demanded these things from Japan, which helped them in their rapid industrialization with foreign technology and patent licenses. In this regard, it is important to promote joint ventures to hasten technological transfer. The government has also to encourage Chinese and Indian projects and companies to use locally made inputs rather than depending entirely on their own consumable and non-consumable products. In this regard, Chinese companies are required to come with open plans for Africa;

4) Project aid must be executed as part of a broader development strategy. Project aid covers many different activities but it is intended for a specific purpose. The main purpose of such aid is to achieve specific and concrete outputs, with many projects attempting to fill gaps by providing resources, skills, and systems which the recipient country needs due to their lack of the required programme aid. Since such programme aid needs to be broader in coverage and objectives, it may either call for a sector-wide approach like budgetary support or target a specific sector (such as education sector among others). In this regard, project aid must be linked to a broader strategy to promote economic growth. It should, for instance, link different infrastructures and such sectors of the economy as agriculture and industry to make full use of their potential network effects in order to bring about such notable development impacts as experienced by Southeast Asia;

5) National planning is important in the efforts to maintain and sustain large scale projects financed or constructed recently by China, India, and other donors. Large scale projects maintenance like infrastructures is cheaper than construction. This can be done either by Ethiopia alone or in close collaboration with China and India to build Ethiopia's capacity to maintain and sustain large scale projects. This needs a strategy to transfer technology from re-emerging donors;

6) Ethiopia and other African countries should come up with proactive policies and strategies and engage BRICS and other traditional donors' development assistances at state, sub regional, and continental levels. In this regards, Ethiopia and other African countries should be prepared for negotiations from a stronger and more informed platform. The Ethiopian government's 5-year Growth and Transformation Plan (GTP) is encouraging because it aims to upgrade the infrastructure level of the country through different mechanisms. One of them is through development assistance from the BRICS countries. At sub regional level, SADEC countries prepared sub regional projects-with a total value that is worth $\$ 42$ billion-on energy, transport, information technology, metrology, tourism, and water sources to be implemented in the next 15 years. And one of their strategies is engaging different donors. At the continental level, African leaders agreed to prioritise the programmes contained in the Priority Action Plan (PAP) of the Programme for Infrastructure Development in Africa (PIDA) and to promote regional projects in energy, transport, and water with specific targets. In this regard, it is important to engage emerging economies on PIDA among others. China also made commitments in the fifth FOCAC to support the African integration process;

7) Ethiopia and other African countries should develop a policy on incremental reduction of dependence on aid. In this 
regard both China and India can be cited as role models. Up until the mid-1990s, India increasingly relied on ODA from OECD countries, at one point even becoming the world's largest aid recipient. However, today, as a consequence of its economic rise, foreign aid has become only a marginal feature in India's overall economic development, accounting for less than $0.3 \%$ of the country's GDP. China's aid as a proportion of GDP also dropped from 0.6 per cent in 1990 to 0.1 per cent in 2003. At the continental level, Africa has currently half a trillion dollars in reserves, strictly around $\$ 510$ billion, which is greater than that of India and Brazil. Africa then must invest some amount of its reserves in an Africa infrastructure Bond, prioritized by the Regional Economic Communities and managed by the African Development Bank (AfDB) or with other arrangement (ECA, 2012).

\section{For China and India}

8) Untying their development assistance is recommended because it is one of the major principles of both the Paris Declaration and Busan Outcomes Documents as well as the eight principles for China's aid to foreign countries;

9) Also recommended is the increase of financial transparency in their development assistance to Ethiopia and other countries through publishing in one report or making the figures accessible, which will help the analysis on the impact of their development assistance on growth, development, aid effectiveness, debt sustainability, etc.;

10) Chinese and Indian development assistance should address the rapidly evolving economic, social and security environments in Ethiopia and Africa. In this regard, they will need to adjust their development assistance accordingly rather than lagging behind; and

11) Finally, China's and India's development assistance also requires cooperation with other donors so that resources are utilized in ways as effective as possible and for the maximum benefit of Africa through their technical assistance in areas of, especially, health, education, and so forth.

\section{Interviews}

Interview with Official of Chinese Commercial Centre in Addis Ababa, Ethiopia 28/06/12, 10-11:30 am, 14/06/12, 2:303:30 pm, 19/06/12, 11-12 pm;

Interview with Ethiopian Telecommunication Corporation (ETC) Officials. 12/07/2012, 4-5 pm;

Interview with Mr Yong, the Media Liaison Official of the Embassy of China, 19/07/12 1:30-2:30 pm;

Interview with MOFED Authority, Indian and Chinese Desks, 12/06/2012, 3-4 pm, and 18/06/12, 4-5 pm;

Interview with EXIM Bank India Official, Addis Ababa, Ethiopia, 19/06/2012 3-5 pm.

\section{REFERENCES}

Ali, S. S. (1987). India and Africa through the ages. New Delhi: National Book Trust.

Bagchi, I. (2012). Former Ethiopia PM Meles Zenawi helped extend India's footprint in Africa. SAFPI.

http://articles.timesofindia.indiatimes.com/2012-08-22/india/333219 091 india-africa-indian-companies-india-and-china

Brautigam, D. (2009). The dragon's gift: The real story of chine in Africa. Oxford: Oxford University Press.

Brautigam, D. (2010). China, Africa and the international aid archi- tecture. African Development Bank Group Working Paper Series, No. 107, April 2010.

Brautigam, D. (2011). China's African bargain: What can western donors learn? The Nordic Africa Development Policy Forum. http://www.naiforum.org/2011/09/china-in-africa/

Brautigam, D. (2011). Chinese development finance in Africa. In Perspectives on Emerging Powers in Africa: Analysis \& Commentary From Fahamu's Emegring Powers in Africa Initiative, Issue 16 December 2011.

Brautigam, D. (2012). Ethiopia’s partnership with China: China sees Ethiopia as a land of business opportunities, but the African country remains in charge of any deals.

http://www.guardian.co.uk/global-development/poverty-matters/201 $\underline{2 /}$

Busia, K. (2011). New partners emerging. http://etalks.tv/blog/2010/10/08/africa-is-gaining-bargaining-power/

Capital News Paper (2012). Chinese firm clinches \$1.6 bln rail way project the Africa Report, Ethiopia.

http://www.capitalethiopia.com/index.php?option=com content\&vie $\mathrm{w}=$ article\&id=1255: chinese-firm-clinches-16-bln-rail-way-project\&c atid=35: capital\&Itemid=27

China Daily/ANN (2011). Chinese Embassy in FDRE. Tue, Aug 16, 2011.

China Embassy in FDRE (2012). CPPCC National Committee Chairman Jia Qinglin accepts a written interview with the Ethiopian news Agency. http://et.china-embassy.org/eng/zagx/t900715.htm

China's Embassy in FDRE (2012). Ethiopia-China cooperation in power sector registers remarkable achievements: Minster. http://et.china-embassy.org/eng/zagx/t827170.htm

Chinese Foreign Affairs (2011). Full Text: China’s foreign aid (White Paper). April 21 $1^{\text {st }}$. http://china-wire.org/?p=11134

ECA (2012). Reflections on Africa's development: Essays in honour of Abdoulie Janneh. Addis Ababa: Economic Commission for Africa.

Embassy of India (2011) India-Ethiopia Bilateral Relations. http://www.indianembassy.gov.et/FINAL_800by600/bilateralrelation htm

Embassy of India (2011). Address by the Prime Minister of India at the Joint Session of the two Houses of the Parliament of Ethiopia. http://www.indianembassy.gov.et/FINAL_800by600/bilateralrelation . $\mathrm{htm}$

Foster, V., et al. (2008). China's emerging role in Africa: Part of the changing landscape infrastructure finance. GRID LINES, Note No. 42, 1-2.

Gedion, G. (2009). Post 1991 Ethio-China relations: Challenges and prospects. http://www.afrology.com

Gedion, G., \& Venkataraman, M. (2009) An analysis of Ethio-China relations during the Cold War. China Report at Siege Publications in New Delhi, 45, 17-22.

Government of India, Ministry of Finance, Department of Economic Affairs. Terms and Conditions and Procedure to be adopted in respect of Government of India (GOI) Supported Exim Bank Lines of Credit (LOC's).

http://finmin.nic.in/the_ministry/dept_eco_affairs/dea.asp

Hackenesch, C. (2011). Competing for development? The European Union and China in Ethiopia. Discussion Paper 3/2011, Stellenbosch: Centre for Chinese Studies, Stellenbosch University.

Indian Ministry of Foreign Affairs. International issues: Ethiopia-Indian relations. http://www.mfa.gov.et/BilateralMore.php

Kone, L. (2011). Holding China accountable for complicity in the Darfur genocide. Consultancy Africa Intelligence, 11 Jan 2011.

Li Anshan (2007). China and Africa: Policy and challenges. China Security, 3, 69-93.

Mathews, K. (1998). Understanding India’s African Policy. In Mansingh, L., et al. (Eds.), Indian Foreign Policy: Agenda for the $21^{\text {st }}$ Century, Vol. 2 (p. 15). New Delhi: Konark Publisher Pvt. Ltd.

Mathews, K. (2012). A new architecture for India-Africa cooperation: The Second India-Africa forum Summit, May 2011. In Perspectives on Emerging Powers in Africa, Fahamu, Cape Town, Issue No. 9, May 2011.

Melendez-Ortiz, R., et al. (2012). The future and the WTO: Confronting the challenges: A collection of short essays. ICTSD Programme on 
Global Economic Policy and Institutions, Geneva: ICTSD.

Ministry of Foreign Affairs of Ethiopia (2012). International issues: Ethiopia-Indian relations. http://www.mfa.gov.et/BilateralMore.php

Moyo, D. (2009). Dead aid: Why aid is not working and how there is another way for Africa. New York: Farrar, Straus and Giroux.

Muhumuza, R. (2012). China skirting corruption in direct aid. Associated Press, Thu, Feb 9, 2012.

Naidu, S., \& Herman, H. (2008). No "Sleeping Walking” in Africa. Global Dialogue, 13, 5.

Naidu, S., \& Herman, H. (2009). Africa's new development partners: China and India-Challenging the staus quo? In H. Abbas, \& Y. Niyiragira (Eds.), Aid to Africa: Redeemer or Coloniser? Fahamu Books: Pambazuka Press.

OECAD (2012). The DAC definition of Official Development Assistance (ODA). http://www.oecd.org/dac/aidstatistics/34086975.pdf

OECD (2012). Trade related south-south cooperation: India. Paris: OECD Conference Centre.

Ramachandran, S. (2007). India Pushes Peoples Power in Africa. http://www.atimes.com/atimes/SouthAsia/IG13Df03.html

SAIIA (2009). The China-Africa toolkit: A resource for African policymakers. China in Africa Project South African Institute of International Affairs (SAIIA), September 2009.

\section{Abbreviations and Acronyms}

$\begin{array}{ll}\text { AfDB } & \text { African Development Bank } \\ \text { AUC } & \text { African Union Commission } \\ \text { BRICS } & \text { Brazil Russia, India, China and South Africa } \\ \text { CADF } & \text { China Africa Development Fund } \\ \text { CCPC } & \text { Committee of Chinese People’s Consultative Con- } \\ \text { ference } & \\ \text { CDMA } & \text { Code Division Multiple Access } \\ \text { CL } & \text { Concessional Loan } \\ \text { DEA } & \text { Department of Economic Affairs } \\ \text { DFID } & \text { Department for International Development } \\ \text { DFTP } & \text { Duty Free Tariff Preference Scheme } \\ \text { DPA } & \text { Development Partnership Administration } \\ \text { DTIS } & \text { Diagnostic Trade Integration Study } \\ \text { ECA } & \text { Economic Commission for Africa } \\ \text { EIF } & \text { Enhanced Integrated Framework } \\ \text { EPRDF } & \text { Ethiopian People Revolutionary Democratic Front } \\ \text { ETC } & \text { Ethiopian Telecommunication Corporation } \\ \text { EXIM } & \text { Export Import Bank } \\ \text { FDRE } & \text { Federal Democratic Republic of Ethiopia } \\ \text { FOC } & \text { Foreign Office Consultations } \\ \text { FOCAC } & \text { Forum on China-Africa Cooperation } \\ \text { GDP } & \text { Growth Domestic Production } \\ \text { GSM } & \text { Global System for Mobile } \\ \text { GTP } & \text { Growth and Transformation Plan }\end{array}$

Shipping News and Views (2012). India offers \$1bn incentive for African infrastructure investment. http://shippingnewsandviews.wordpress.com/2012/06/13/india-offers -1bn-incentive-for-african-infrastructure-investment/

Singh, G. (2008). India and the Ethiopian Economy. In The $6^{\text {th }}$ International Conference on the Ethiopian Economy, United Nations Conference Center, Addis Ababa, 5 July 2008.

Tandon, Y. (2008). Ending aid dependence. Fahamu.

The $4^{\text {th }}$ High Level Forum on Aid Effectiveness (2011). Busan, Republic of Korea. Busan Partnership for Effective Development Co-operation, 29 Nov-1 Dec, 2011.

The Reporter (2011). (Amharic), 21 December 2011, Vol. 17, No. 14. www.ethiopianreporter.com

The Reporter (2011). (Amharic), 28 December 2011, Vol. 17, No. 15. www.ethiopianreporter.com

The Reporter (2011). China provided 500 million USD to 15 different projects in Ethiopia. The Reporter (The Amharic News Paper), 20 August 2011. Vol. 16, No. 50. www.ethiopianreporter.com

William, E. (2006). The white man's burden: Why the west's efforts to aid the rest have done so much ill and so little good. New York: The Penguin Press.
HIPC Heavily Indebted Poor Countries

ICBC Industrial and Commercial Bank of China

ICT International Consultants and Technocrats

IMF International Monetary Fund

ITEC Technical and Economic Co-operation

JECC Joint Ethiopia-China Commission

JMC Joint Ministerial Commission

JTC Joint Trade Committee

LDCs Least Developed Countries

LOC Lines of Credit

MEA Ministry of External Affairs

MOFCOM Ministry of Commerce

MOFED Ministry of Finance and Economic Development

PAP Priority Action Plan

PIDA Programme for Infrastructure Development in

Africa

PRC Peoples Republic of China

SADEC Southern Africa Development Community

SMEs Small and Medium Enterprises

TCS Technical Co-operation Scheme

TVET Technical and Vocational Training

WTO World Trade Organization

ZTE Zhong Xing Telecommunication Equipment Com-

pany 